\title{
Rodzina podmiotem ewangelizacji w Kościele pierwotnym
}

Termin „ewangelizacja” wywodzi się od greckiego słowa euangelion (dobra nowina, radosna wiadomość, ewangelia) oraz czasownika euangelidzein i jego form imiesłowowych (zwiastujący, głoszący, przekazujący, krzewiący dobrą nowinę $)^{1}$. W świetle tekstów biblijnych jest przede wszystkim „synonimem przepowiadania kerygmatycznego i oznacza proklamację zbawienia w Jezusie Chrystusie tym, którzy Go nie znają"2. W szerokim rozumieniu obejmuje on całą misję Kościoła, bowiem „treść całego jego życia stanowi traditio Evangelii - głoszenie i przekazywanie Ewangelii, która jest „mocą Bożą ku zbawieniu dla każdego wierzącego” (Rz 1,16), a w swej najgłębszej istocie utożsamić ją można z Jezusem Chrystusem (por. 1 Kor 1,24)"3. Adresatem tak rozumianej ewangelizacji jest zatem cała ludzkość.

1 Por. A. Lewek, Nowa ewangelizacja $w$ duchu Soboru Watykańskiego II, Katowice 1995, s. 21-23; T. Hergesel, Ewangelizacja w Biblii, w: W kręgu Dobrej Nowiny, red. J. Szlaga, Lublin 1984, s. 87-95; R. Fisichella, La nuova evangelizzazione, Milano 2011, s. 17.

2 W. Przyczyna, Teologia ewangelizacji, Kraków 1992, s. 26.

3 Kongregacja Nauki Wiary, Nota doktrynalna na temat pewnych aspektów ewangelizacji, „L'Osservatore Romano” wyd. pol. 2 (2008) nr 2, s. 32-33. 
Ewangelizacja stanowiła zadanie Kościoła od początku jego istnienia. Apostołowie otrzymali od Chrystusa polecenie: „Idźcie na cały świat i głoście Ewangelię wszelkiemu stworzeniu; idźcie więc i nauczajcie wszystkie narody" (Mk 16,15; Mt 28,19). Rozpoczęli więc wypełnianie tego polecenia najpierw w Jerozolimie: „w imię Jego głoszone będzie nawrócenie i odpuszczenie grzechów wszystkim narodom, począwszy od Jeruzalem” (Łk 24,47), a później rozeszli się „aż po krańce ziemi” (por. Dz 1,8). Ewangelizacja dokonywała się także wewnątrz Kościoła, rodząc go i umacniając ochrzczonych: „Trwali oni w nauce Apostołów i we wspólnocie, w łamaniu chleba i w modlitwach" (Dz 2,42). Ewangelizacja oznacza zatem głoszenie Jezusa Chrystusa dokonywane zarówno przez przykład życia, jak i głoszone słowo.

Prezentując zagadnienie rodziny jako podmiotu ewangelizacji w pierwotnym Kościele, należy przedstawić zarys ewangelizacji w pierwotnym Kościele w świetle Dziejów Apostolskich, udział rodziny w dziele ewangelizacji, a także oikos (dom) jako miejsce ewangelizacji w świetle niektórych tekstów Nowego Testamentu.

\section{Ewangelizacja w świetle Dziejów Apostolskich}

Głoszenie orędzia zbawienia jest jednym z najistotniejszych tematów teologicznych św. Łukasza, zarówno w Ewangelii, jak i w Dziejach Apostolskich ${ }^{4}$, które stanowią drugą część jego dzieła i zawierają historię pierwotnego Kościoła ${ }^{5}$. Wcześniej Łukasz przedstawia Jezusa jako zwiastuna radosnej nowiny, który ją głosi ubogim, uwięzionym i chorym (por. Łk 4,18-19) ${ }^{6}$. Dalej, w księdze Dziejów Apostolskich, ukazuje świadectwo dawane Jezusowi i zrodzone z niego życie pierwszych wspólnot chrześcijańskich. Łukasz

\footnotetext{
4 Por. M. Rosik, Duch Święty - źródło odwagi w głoszeniu słowa zbawienia (Dz 4,2331), „Verbum Vitae” 2, s. 151.

5 Jak mówi Ryszard Kempiak, „dzisiaj wszyscy egzegeci są zgodni co do tego, że trzecia Ewangelia i Dzieje Apostolskie, choć aktualnie znajdują się w kanonie Nowego Testamentu oddzielnie - stanowią jedno dzieło w dwóch częściach (...)”. R. Kempiak, „Będziecie moimi świadkami [...] aż po krańce ziemi” (Dz 1,8). Kompozycja Dziejów Apostolskich, „Scriptura Sacra" 1 (1997) 1, s. 75.

6 Por. T. Hergesel, Biblijna idea ewangelizacji, „Colloquium Salutis, Wrocławskie Studia Teologiczne" 11 (1979), s. 265.
} 
pisze swoje dzieło w okresie dynamicznego rozwoju misji ewangelizacyjnej pierwotnej wspólnoty chrześcijańskiej ${ }^{7}$. Dzieje Apostolskie pokazują, w jaki sposób przebiegała ewangelizacja w pierwotnym Kościele, wskazują osoby, które miały wpływ na rozszerzanie się słowa Bożego, i na wkład rodziny $\mathrm{w}$ dzieło ewangelizacji.

Mówiąc o rozszerzaniu się Słowa Bożego w Dziejach Apostolskich, trzeba zacząć od ogólnej struktury księgi i zawartych w niej treści. Najczęściej strukturę księgi bada się w oparciu o kryteria biograficzne, geograficzne i tematyczne ${ }^{8}$. W Dziejach Apostolskich widoczny jest pewien dynamizm geograficzno-teologiczny, pokazany w $\mathrm{Dz} 1,8^{9}$. Ten schemat i podział wg Dz 1,8 jest jednym z najbardziej przekonujących i pozostaje w zgodzie z logiką dzieła. Najpełniej też oddaje proces ewangelizacji i rozszerzanie się słowa Bożego w ówczesnym świecie ${ }^{10}$.

W Dziejach Apostolskich widzimy uniwersalistyczną wizję dawania świadectwa „aż po krańce świata” (Dz 1,8)”11. Fragment Dz 1,8 to kluczowe zdanie, które pokazuje, jak rozszerzała się Ewangelia. Zgodnie z tym wersetem chrześcijaństwo zaczęło się w Jerozolimie, potem rozprzestrzeniło na Judeę i Samarię, a w końcu sięgnęło aż po krańce ziemi: „będziecie moimi świadkami w Jeruzalem i w całej Judei, i w Samarii, i aż po krańce ziemi" (Dz 1,8).

$\mathrm{W}$ badaniach najczęściej przyjmuje się istnienie trzech etapów rozwoju dzieła ewangelizacji w Dziejach Apostolskich. Każdy z nich poprzedzony jest zapowiedzią Ducha Świętego, który uzdolni uczniów do dawania świadectwa w całym świecie, począwszy od Jerozolimy (Łk 24,47-49; Dz 1,8$)^{12}$. Pierwszy etap, według fragmentu Dz 1,8 , dotyczy działalności apostolskiej w Jerozolimie (Dz 2,1-8,3), która jest punktem wyjścia misji

7 Por. R. Kempiak, „Będziecie moimi świadkami..., dz. cyt., s. 77; zob. szerzej: M. Simon, Cywilizacja wczesnego chrześcijaństwa, tłum. E. Bąkowska, Warszawa 1981, s. 29-45.

8 Szerzej na ten temat w: W. Rakocy, „A słowo Boże rozszerzało się i rosło”. Programowa funkcja Dz 12,1-24 w kompozycji ksiegi, Lublin 1995, s. 55-60; W. Rakocy, Przyczynek do dyskusji na temat kompozycji dziejów Apostolskich, „Roczniki Teologiczne” t. XLII (1995) 1, s. $103-110$.

9 Por. W. Rakocy, A słowo Boże rozszerzało się i rosło..., dz. cyt., s. 62.

10 Por. W. Rakocy, Przyczynek do dyskusji na temat kompozycji dziejów Apostolskich, dz. cyt., s. 104; w celu zobaczenia szerszego planu Dziejów Apostolskich odsyłam także do: R. Kempiak, Będziecie moimi świadkami..., dz. cyt., s. 84-88.

11 Papieska Komisja Biblijna, Naród Żydowski i jego Święte Pisma w Biblii chrześcijańskiej, Kielce 2002, s. 149.

12 Por. W. Rakocy, A słowo Boże rozszerzało się i rosło..., dz. cyt., s. 61. 
ewangelizacyjnej (Dz 1,8b) ${ }^{13}$. Drugi etap to działalność misyjna w Judei i Samarii (por. Dz 8,4-11,18) ${ }^{14}$. Trzeci i ostatni - ma początek w chwili przybycia pierwszych wyznawców do Fenicji, na Cypr i do Antiochii (por. Dz 11,19) i zajmuje ostatnią część Dziejów Apostolskich (por. Dz 28,31) ${ }^{15}$.

Głoszenie „wszystkim narodom począwszy od Jeruzalem” (por. Łk 24,47b; $\mathrm{Dz} 1,8)^{16}$ zapowiada oprócz planu geograficznego również plan teologiczny Dziejów Apostolskich ${ }^{17}$. Misyjny nakaz Jezusa w redakcji Łukasza zawiera trzy elementy:

- Głoszenie nawrócenia i odpuszczenia grzechów (por. Łk 24,47).

- Dawanie świadectwa wydarzeniom zbawczym dokonanym w przyjściu Chrystusa (por. Dz 1,8; Łk 24,48).

- Naznaczenie początku ewangelizacji (por. Łk 24,47; Dz 1,8) ${ }^{18}$.

Głoszenie nawrócenia wiązało się ze sposobem zmiany myślenia, usposobienia, autentycznego zwrócenia się do Boga. Nawrócenie oznacza misję, a wiara - dzielenie się ${ }^{19}$. Jezus Chrystus łączy ściśle wezwanie do nawrócenia z przepowiadaniem królestwa Bożego: „Czas się wypełnił i bliskie jest królestwo Boże, nawracajcie się i wierzcie w Ewangelię” (Mk 1,15). W osobie Jezusa, w Jego słowach i czynach, obecne jest królestwo ze wszystkimi swoimi mocami zbawczymi. Dlatego właśnie wezwania do nawrócenia są istotnym celem Jego misji: „Nie przyszedłem powołać do nawrócenia się sprawiedliwych, lecz grzeszników” (Łk 5,32). W nakazie misyjnym zadanie to powierza apostołom: „W imię Jego głoszone będzie nawrócenie i odpuszczenie grzechów wszystkim narodom, począwszy od Jeruzalem” (Łk 24,47).

13 Por. J. Kudasiewicz, Jeruzalem - punktem wyjścia misji ewangelizacyjnej (Łk 24,47n; Dz 1,8), w: Materiaty Kongresu Biblijnego w Krakowie 6-8 czerwca 1972 r., red. S. Grzybek. J. Chmiel, Kraków 1974, s. 125.

14 Dalej niespodziewanie pojawia się też Galilea: „A Kościół cieszył się pokojem w całej Judei, Galilei i Samarii” (Dz 9,31a).

15 Por. W. Rakocy, Przyczynek do dyskusji na temat kompozycji Dziejów Apostolskich, dz. cyt., s. 104; R. Kempiak, Będziecie moimi świadkami..., dz. cyt., s. 76-79.

16 Por. J. Kudasiewicz, Jeruzalem - punktem wyjścia misji ewangelizacyjnej..., dz. cyt., s. $137-141$.

17 Por. W. Rakocy, A słowo Boże rozszerzało się i rosło..., dz. cyt., s. 62; J. Kudasiewicz, Jeruzalem - punktem wyjścia misji ewangelizacyjnej..., dz. cyt., s. 126.

18 Por. W. Rakocy, A słowo Boże rozszerzało się i rosło..., dz. cyt., s. 62; J. Kudasiewicz, Jeruzalem - punktem wyjścia misji ewangelizacyjnej..., dz. cyt., s. 128-129.

19 Por. A. G. Hamman, Życie codzienne pierwszych chrześcijan (95-197), tłum. U. Sudolska, A. Guryn, Warszawa 1990, s. 94. 
Nawrócenie łączy się także z odpuszczeniem grzechów ${ }^{20}$. Zachodzi tu pewna zgodność pomiędzy „głoszeniem wszystkim ludom” i „świadectwem aż po krańce ziemi" ${ }^{21}$.

Następnym zadaniem apostołów jest dawanie świadectwa: „Będziecie moimi świadkami” (por. Dz 1,8; Łk 24,48). Apostołowie są świadkami ważnych wydarzeń: męki, śmierci i zmartwychwstania Jezusa (por. Łk 24, 44-46; Dz 1,21-22) 22. We fragmencie Łk 24,48: „Wy jesteście świadkami tego" podana jest więc podstawa świadectwa, czyli osobisty kontakt $\mathrm{z}$ wydarzeniami. Natomiast w Dz 1,8: „będziecie moimi świadkami” sformułowano nakaz bycia świadkiem ${ }^{23}$. Forma ta ma charakter „prawniczego świadczenia" ${ }^{24} \mathrm{o}$ Zmartwychwstałym Panu $\mathrm{z}$ wezwaniem do wiary w Niego (por. Dz 13,27-31; 10,39-41), a Apostołowie są w nim umocnieni przez Ducha

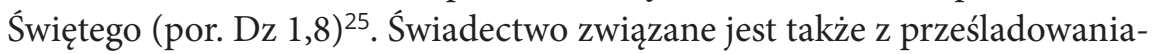
mi i trudnościami (por. Dz 22,20). Być świadkiem Jezusa oznacza z mocą Ducha i z głębokim przekonaniem świadczyć wobec Żydów i pogan o Jego Zmartwychwstaniu, będąc gotowym nawet do przelania krwi dla dobra świadectwa ${ }^{26}$.

20 Por. J. Kudasiewicz, Jeruzalem - punktem wyjścia misji ewangelizacyjnej..., dz. cyt., S. 131 .

21 Por. R. Kempiak, Będziecie moimi świadkami..., dz. cyt., s. 82.

22 Por. J. Gnilka, Teologia Nowego Testamentu, tłum. W. Szymona OP, Kraków 2002, s. $14-23$.

23 Por. K. Luke, Biblijne pojęcie martyria (świadectwa), w: Ewangelizacja, dialog i rozwój - wybrane dokumenty Międzynarodowej Konferencji Teologicznej w Nagpur w 1971 r., red. M. Dhavamon, tłum. J. Marzęcki, Warszawa 1986, s. 80.

24 Termin martyr (świadek): „Zaczerpnięty został z języka prawniczego i oznacza człowieka, który przez własne i bezpośrednie doświadczenie jest w stanie wydać jakiś sąd o wydarzeniach, w których uczestniczył lub na które osobiście patrzył, względnie o osobach i okolicznościach, które zna z własnego oglądu. Dzięki temu może być powołany na oficjalnego świadka w procesie sądowym lub też w innych prawnych aktach o charakterze społecznym. Termin ten był również używany poza środowiskiem jurydycznym. Oznaczał on wtedy człowieka, który może zaświadczyć o faktach lub osobach, które poznał osobiście. Oznacza również człowieka, który publicznie ujawnia swe przekonanie lub przeświadczenie odnośnie do jakiejś prawdy religijnej lub filozoficznej. Łukasz świadomie używa tu tego słowa, do ludzi, którzy bezpośrednio zetknęli się z Jezusem lub Go doświadczyli w swoim życiu”. J. Kudasiewicz, Jeruzalem - punktem wyjścia misji ewangelizacyjnej..., dz. cyt., s. 131-134.

25 W. Cyran, Rola Ducha Świętego $w$ dziele ewangelizacji (na podstawie Dz 10,44-48), „Częstochowskie Studia Teologiczne” XXI-XXII (1993-1994), s. 15-36.

26 Por. J. Kudasiewicz, Jeruzalem - punktem wyjścia misji ewangelizacyjnej..., dz. cyt., s. 134 . 
Według Łukasza głoszenie nawrócenia i dawanie świadectwa o Jezusie przez apostołów i uczniów miało rozpocząć się w Jerozolimie. Nakaz misyjny, który Zmartwychwstały dał apostołom, nie miał się jednak zamknąć tylko w tym mieście, ale winien był się rozciągnąć również na Judeę, Samarię i aż na krańce ziemi. Apostołowie byli świadkami męki, śmierci, zmartwychwstania oraz głoszenia w imię Jezusa. Według Łukasza to Jerozolima jest punktem wyjścia świadectwa o zmartwychwstaniu i głoszeniu dobrej nowiny zbawienia „aż po krańce świata”. Księga Dziejów Apostolskich kończy się nagle opisem pobytu Pawła w Rzymie, w którym przebywał on, „głosząc królestwo Boże i nauczając o Panu Jezusie Chrystusie zupełnie swobodnie, bez przeszkód" (Dz 28,31). Tym ostatnim etapem rozwoju chrześcijaństwa, a według Dz 1,8 krańcem ziemi, jest Rzym, do którego Łukasz doprowadza Ewangelię za pośrednictwem Pawła ${ }^{27}$.

Innymi miejscami rozprzestrzeniania się chrześcijaństwa były Judea i Samaria (Dz 8-9) i wiązały się one z osobami apostołów Piotra i Jana oraz działalnością Filipa (Dz 8,4-40). Później, od nawrócenia Korneliusza, rozpoczął się pochód Ewangelii aż po krańce ziemi, do Rzymu (Dz 10n). Oznacza to przejście Ewangelii z Jeruzalem i obszarów zajmowanych przez Żydów do Rzymu - stolicy ówczesnego świata pogańskiego ${ }^{28}$.

Dzieło ewangelizacji było mocno związane z wyprawami misyjnymi św. Pawła. Możemy w nich zobaczyć rozszerzanie się słowa Bożego: „A słowo Pańskie szerzyło się i rosło” (Dz 12,24), wzrost Kościoła: „Tak więc utwierdzały się Kościoły w wierze i z dnia na dzień rosły w liczbę” (Dz 16,5) i coraz większy zasięg słowa Pańskiego: „Tak rosło w potęgę i umacniało się słowo Pańskie (Dz 19,20) ${ }^{29}$.

Tekst Dz 11,19-21 podaje dalszą informację na temat rozszerzania się Dobrej Nowiny nie tylko pośród Żydów, ale także Greków. Paweł i Barnaba, na zakończenie mowy w Antiochii Pizydyjskiej, stwierdzają: „Należało głosić Słowo Boże najpierw wam. Skoro jednak odrzucacie je i sami uznajecie się za niegodnych życia wiecznego, zwracamy się do pogan” (Dz 13,46). Ta decyzja jest równocześnie wypełnieniem nakazu Pana zawartego w Piśmie: „Ustanowiłem Cię światłością dla pogan, abyś był zbawieniem, aż po

\footnotetext{
27 Por. J. Kudasiewicz, Jeruzalem - punktem wyjścia misji ewangelizacyjnej..., dz. cyt.,

28 Por. J. Kudasiewicz, Jeruzalem - punktem wyjścia misji ewangelizacyjnej..., dz. cyt.,

29 Por. W. Rakocy, A słowo Boże rozszerzało się i rosło..., dz. cyt., s. 88.
} s. 142. s. 145. 
krańce ziemi" (Dz 13,47; por. Iż 49,6) ${ }^{30}$. Podobną argumentację spotykamy w rzymskiej mowie św. Pawła do Żydów (Dz 28,25-28). Zbawienie Boże zostaje w niej posłane poganom, którzy będą mu posłuszni, ponieważ lud izraelski - zgodnie z zapowiedzią proroka Izajasza (Iz 6,9n) - nie jest chętny do słuchania i ma otępiałe serca.

Podatnym gruntem dla Słowa Bożego w środowisku pogańskim okazały się Antiochia w Azji Mniejszej: „Poganie, słysząc to, radowali się i wielbili Słowo Pańskie, a wszyscy przeznaczeni do życia wiecznego, uwierzyli. Słowo Pańskie szerzyło się na cały kraj” (Dz 13,48-49); Grecja (Korynt): „A kiedy się sprzeciwiali i bluźnili, otrząsnął swe szaty i powiedział do nich (Paweł): Krew wasza na wasze głowy, ja nie jestem winien. Od tej chwili pójdę do pogan” (Dz 18,6); Italia (Rzym): „Przez całe dwa lata pozostał w wynajętym przez siebie mieszkaniu i przyjmował wszystkich, którzy do niego przychodzili, głosząc królestwo Boże i nauczając o Panu Jezusie Chrystusie" (Dz 28,30-31). Ponieważ Żydzi odrzucali Dobrą Nowinę o Jezusie, dlatego kieruje się ona do pogan ${ }^{31}$. Dz 11,19-21 zapowiadają pewien przełom, jaki dokonuje się w głoszeniu Dobrej Nowiny, zarówno Żydom, jak i Grekom. W ten sposób realizował się Boży zamiar (por. Dz 9,15; 11,21a), a także rodziła się wiara i dokonywało się nawrócenie: „A ręka Pańska była z nimi, bo wielka liczba uwierzyła i nawróciła się do Pana" (Dz 11,21) ${ }^{32}$.

Dzieje Apostolskie opisują, w jaki sposób słowo Boże rozszerzało się i jak nakaz misyjny został spełniony. Łukasz posłużył się „schematem geograficznym", aby ukazać postęp Ewangelii w świecie ${ }^{33}$, dlatego świadectwo o Zmar-

30 Por. R. Kempiak, Będziecie moimi świadkami..., dz. cyt., s. 82.

31 Warto dodać, że „punktem zwrotnym jest tu historia Szczepana. Następuje tutaj zerwanie z judaizmem jerozolimskim i świątynią, a zwrócenie się do pogan. Do czasu męczeństwa Szczepana lud jerozolimski, w przeciwieństwie do swych przywódców, otwierał się na Ewangelię i jej przepowiadanie (Dz 2,47; 3,10; 4,21; 5,12n; 5,16). W momencie męczeństwa, łącząc się z przywódcami kamienowania Szczepana, sami wyłączyli się ze zbawienia głoszonego przez wyznawców Jezusa”. J. Kudasiewicz, Jeruzalem - punktem wyjścia misji ewangelizacyjnej..., dz. cyt., s. 146; por. także: J. Łach, Rola gminy jerozolimskiej w pierwotnym Kościele (Dz 2,42-47; 4,32-35; 5,12-16), w: Scrutamini Scripturas - Księga pamiątkowa z okazji jubileuszu ks. prof. Stanisława Łacha, Kraków 1980, s. 88-89.

32 Orędzie o Jezusie Chrystusie wychodzi poza Jerozolimę dzięki prześladowaniu, które było zwrócone przeciwko tamtejszej wspólnocie chrześcijańskiej. Por. W. Rakocy, A słowo Boże rozszerzało się i rosło..., dz. cyt., s. 63.

33 Por. J. Kudasiewicz, Jeruzalem - punktem wyjścia misji ewangelizacyjnej..., dz. cyt., s. 148 . 
twychwstałym powinno być nadal dawane, a nakaz misyjny realizowany przez konkretne osoby zaangażowane $\mathrm{w}$ dziele ewangelizacji.

\section{Udział rodziny w dziele ewangelizacji}

W Kościele pierwotnym chrześcijaństwo rozprzestrzeniało się w kręgach rodziny, miejscach pracy, codziennych spotkań. Mocno zaangażowane w dzieło misyjne były także pary małżeńskie, czego przykładem są niewątpliwie Pryscylla i Akwila. Wygnani na podstawie edyktu cesarza Klaudiusza z Rzymu (por. Dz 18,2), zaczynają głosić Dobrą Nowinę w nowych miejscach pobytu, a ich domy w Koryncie (por. Dz 18,1-4), w Efezie (por. Dz 18,18n.26; 1 Kor 16,19) i w końcu znowu w Rzymie (Rz 16,3-5) stały się centrum misji Pawłowej. Pryscylla i Akwila gromadzą wokół siebie wspólnotę chrześcijan. Paweł pięknie wspomina ich działalność w Liście do Rzymian (por. Rz 16,3-4) 34. Świadectwo o Zmartwychwstałym objawia się nie tylko w osobach, które bezpośrednio spotkały Chrystusa, ale obecne jest także w życiu i działalności innych, w tym także małżeństw i rodzin zaangażowanych w dzieło ewangelizacji.

Według Dziejów Apostolskich pierwsi chrześcijanie w Jerozolimie znali dwa typy zgromadzeń. Spotykali się na modlitwę w świątyni (Dz 2,46), często w krużganku Salomona (Dz 3,11; 5,12), a po odłączeniu się od synagog żydowskich zbierali się także $\mathrm{w}$ domu $(\mathrm{Dz} 2,46 ; 5,42)^{35}$. Nowy Testament ukazuje zatem pierwszorzędną rolę domu i rodziny w rozwoju Kościoła, $\mathrm{w}$ jego posłannictwie ewangelizacyjnym i życiu sakramentalnym ${ }^{36}$.

Pierwszymi, którym głosi się Ewangelię, są członkowie rodziny. Dom stawał się miejscem gromadzenia chrześcijan na modlitwę, wspólny posiłek i „łamanie chleba” (por. Dz 2,46; 16,15; Kol 4,15). Należy przy tym pamiętać, że oprócz małżonków i dzieci do rodziny zaliczano także służbę i niewolników (por. Flm 10), a wiara ojca odgrywała decydującą rolę i zazwyczaj przyjmowana była przez resztę domowników (por. Dz 11,14; 16,15.31; 18,8;

\footnotetext{
34 Por. H. J. Klauck, Wczesnochrześcijańska wspólnota kościelna, Kraków 1995, s. 94-95.

35 Por. J. A. Fitzmyer, Lettera ai Romani. Commentario critico-teologico, Casale Monferrato 1999, s. 869.

36 J. Grześkowiak, U źródeł terminu „Kościót Domowy”, „Roczniki Teologiczne Lublin” t. XXXII (1985) 2, s. 172.
} 
1 Kor 1,16; 16,15; J 4,53) ${ }^{37}$. Dom chrześcijański był otwarty dla innych w ramach gościnności i ze względu na Chrystusa. Był miejscem spotkań, a także zalążkiem misji ewangelizacyjnej i pierwszym Kościołem. Rodzina dawała przykład nawrócenia i to z jej domu płynęły na dalsze domy misjonarskie impulsy. Pierwsze utworzone większe społeczności chrześcijańskie opierały się na tych „Kościołach domowych” (por. 1 Kor 16,15) ${ }^{38}$, a właściciele niewolników ewangelizowali swoją służbę, co zmieniało stosunki między domownikami i usuwało bariery między nimi.

Jako że domy rodzinne stanowiły centra życia religijnego pierwszych chrześcijan, były bazą, z których mogła być podjęta dalsza ewangelizacja $\mathrm{w}$ miastach ${ }^{39}$. Spotkania wierzących $\mathrm{w}$ domach stanowiły również pierwszą próbę oddzielenia chrześcijaństwa od synagogi ${ }^{40}$. Zwyczaj gromadzenia się $\mathrm{w}$ domach celem modlitwy i sprawowania kultu był opisywany wielokrotnie w Dziejach Apostolskich (por. Dz 1,13; 2,1.42.46; 5,42; 9.11; 10,31.44-48; $12,12 ; 16,15.40 ; 17,5-7 ; 18,7 ; 20,7-8.20 ; 21,8 ; 28,31-32)$. W Nowym Testamencie często spotykamy wzmianki o domach modlitwy: dom Akwili i Pryscylli (Rz 16,4-5; 1 Kor 16,19), Arystobula (Rz 16,10), Narcyza (Rz 16,11), Gajusa (Rz 16,23), Cezara (Flp 4,24), Stefanasa (1 Kor 1,16; 16,15), Nimfasa (Kol 4,15), Onezyfora (2 Tm 1,16; 4,19) czy Archipa (Flm 1,2). Domostwa te o określonych porach dnia stawały się miejscami modlitwy, ewangelizacji, katechizacji i sprawowania Eucharystii. Właśnie dzięki temu zwano je „kościołami domowymi”.

Warto jeszcze zwrócić uwagę na gościnność, która była cnotą w rodzinie pogańskiej i żydowskiej i która stała się także cnotą chrześcijańską. Kto przyjmuje obcego, przybysza, gościa przyjmuje samego Chrystusa (por. Mt 25,35; 10,10). Cecha ta wnosiła także istotny wkład w dzieło

37 Por. H. Langkammer, Kościoły Domowe w Nowym Testamencie, w: Biblia o rodzinie, red. G. Witaszek, Lublin 1995, s. 10.

38 Jak pisze M. Marczewski: „pojęcie «Kościół domowy» zawiera w sobie dwa znaczenia: małżeństwo i rodzina jako wspólnota realizująca i budująca Kościół oraz jako miejsce sprawowania kultu liturgicznego w okresie pierwszych trzech wieków życia Kościoła”. M. Marczewski, Miejsce i rola małżeństw w misji wczesnochrześcijańskiej na przykładzie Nowego Testamentu (Kościół Domowy), „Vox Patrum. Antyk Chrześcijański” 15 (1988), s. 575583; por. H. Langkammer, Kościoły Domowe w Nowym Testamencie, dz. cyt., s. 11.

39 Por. H. J. Klauck, Wczesnochrześcijańska wspólnota kościelna, dz. cyt., s. 23-24.

40 Por. J. Grześkowiak, Misterium małżeństwa. Sakrament małżeństwa jako symbol przymierza Boga z ludźmi, Poznań 1993, s. 231-245. 
ewangelizacji, gdyż to dzięki niej można było pozyskiwać dla wiary nowe osoby $^{41}$. I tak np. Gajus miał warunki, by podczas spotkań w swoim domu gościć całą wspólnotę korynckąa ${ }^{42}$. Dzięki gościnności rodziny takie były dla wspólnoty chrześcijan centrami promieniowania wiary. Kościół pierwotny uznał oikos, a więc grecko-rzymski miejski dom rodzinny, za duszpasterską podstawę chrześcijaństwa (por. 1 Kor 16,19; Rz 16,5; Flm 2; Kol 4,15)³.

U św. Pawła spotykamy „Kościół konstytuujący się na sposób domowy” (por. 1 Kor 16,19), który tworzyli m.in. Akwila i Pryscylla. Ich chrześcijańska rodzina stanowiła silne centrum kościelne, a w domu tym chrześcijanie gromadzili się regularnie na wspólne spotkania, modlitwę, uczty miłości i liturgię $e^{44}$. Sam Paweł miał za sobą skuteczne doświadczenie prowadzenia kościoła domowego z Akwilą i Pryscyllą (por. Dz 18,1-3), stąd wiedział, że rodziny i ich domy sprzyjały ewangelizacji miasta ${ }^{45}$.

Jest zrozumiałe, że dopóki chrześcijanie nie mieli własnych budynków kultu, dom odgrywał bardzo ważną rolę w ewangelizacji. Paweł, gdy przybywa po raz pierwszy do jakiegoś miasta, kieruje się zwykle do Żydów, do synagogi, ale nie zawsze jest dobrze przyjmowany ${ }^{46}$. W ówczesnym oikos stojący na czele domu małżonkowie, stając się chrześcijanami, okazywali się gorliwymi misjonarzami i apostołami, a ich domy centrami chrześcijańskiej misji ${ }^{47}$.

Duże znaczenie w powstawaniu pierwszych wspólnot chrześcijańskich miały kobiety. Gdy chrześcijanie gromadzili się w domach prywatnych, to właśnie one zabiegały o wszystko, co wiązało się z gościnnością, wywierały też decydujący wpływ na klimat wspólnoty. Kobiety pełniły odpowiedzialne

41 Por. J. K. Pytel, Gościnność w Biblii - studium źródłowo-porównawcze, Poznań 1990, s. $67-90$.

42 Por. H. J. Klauck, Kościót Domowy w okresie przedkonstantyńskim, „Vox Patrum. Antyk Chrześcijański” 8-9, s. 177-191.

43 M. Marczewski, Miejsce i rola małżeństw w misji wczesnochrześcijańskiej..., dz. cyt., s. $575-583$.

44 Por. H. J. Klauck, Wczesnochrześcijańska wspólnota kościelna, dz. cyt., s. 24-33.

45 H. J. Klauck pisze, że: „Możemy przyjąć, że w początkowej fazie w Koryncie (...) wokół Pryski, Akwili i Pawła wykrystalizował się po raz pierwszy Kościół domowy”. H. J. Klauck, Wczesnochrześcijańska wspólnota kościelna, dz. cyt., s. 31; zob. szerzej: J. Murphy-O’Connor, Prisca and Aquila, „Biblia Revuo” 8/6 (1992), s. 40-62.

46 Por. J. Grześkowiak, Misterium małżeństwa, dz. cyt., s. 233.

47 Por. M. Marczewski, Miejsce i rola małżeństw $w$ misji wczesnochrześcijańskiej..., dz. cyt., s. 583 . 
zadania w ewangelizacji - Lidia, Febe, Pryscylla, która ewangelizuje Apollosa (Dz 18,26). Paweł często docenia ich trud i je wspomina (por. Flp 4,2) ${ }^{48}$.

W rodzinie chrześcijańskiej jako wspólnocie, której wszyscy członkowie wyznają prawdziwą wiarę, modlą się i postępują według prawa miłości, są szczególnie obecni Chrystus i Kościół. Odniesienie Chrystusa do Kościoła jest idealnym modelem chrześcijańskich relacji małżeńskich, które winny być całkowicie przeniknięte miłością.

Jak już zaznaczono, rodzina była jednym ze środowisk, w których Ewangelia znalazła swoje miejsce i gościła w codziennym życiu. „Uderzająca jest ich obecność w życiu ludzi, w sklepikach i warsztatach, obozach i miejscach publicznych. Uczestniczą oni w życiu gospodarczym i społecznym, tkwią w codziennych zajęciach i żyją jak wszyscy. (...) Poprzez uczestnictwo chrześcijan w życiu zbiorowym ludzie dojrzewają do nawrócenia"49.

To rodziny jako świadkowie Jezusa Chrystusa ewangelizują swoim życiem przemienionym przez Ewangelię i stają się wyraźnym znakiem obecności i działania Chrystusa w ich życiu. To ona staje się świadkiem Zmartwychwstałego Chrystusa, jego obecności i działania w codziennym życiu, jest także odbiorcą misyjnego nakazu głoszenia Ewangelii „aż po krańce świata" (por. Dz 1,8). To właśnie rodziny chrześcijańskie współpracowały $\mathrm{z}$ apostołami i innymi osobami zaangażowanymi $\mathrm{w}$ rozszerzanie się słowa Bożego. Wspólnoty te głosiły Dobrą Nowinę o Chrystusie, stając się jej wiarygodnymi świadkami.

\section{Oikos miejscem przekazu wiary}

Codzienność rodziny koncentrowała się głównie $\mathrm{w}$ domu - oikos ${ }^{50}$. Pod tym względem życie chrześcijan nie różniło się od życia przedstawicieli innych wyznań. Na rodzinę chrześcijańską należy patrzeć przez pryzmat rodziny żydowskiej i grecko-rzymskiej, bo na bazie tych wzorców kulturowych zrodził się jej nowy model. Pierwsi chrześcijanie pochodzili ze świata

48 Por. K. Romaniuk, Święty Paweł o kobietach, „Colloqium Salutis. Wrocławskie Studia Teologiczne" 21-22 (1989-1990), s. 51-98.

49 A. G. Hamman, Życie codzienne pierwszych chrześcijan (95-197), dz. cyt., s. 104-105.

50 Por. J. Suchy, Wspólnota wierzących jako dom w Pierwszym Liście św. Piotra, w: Biblia o rodzinie, dz. cyt., s. 69-86. 
żydowskiego i grecko-rzymskiego i to w nim przebywali. Także i pod tym względem przykładem są Pryscylla i Akwila (por. Dz 18,1-2). Obszar domu i rodziny, w której żyli już dotychczas jako małżonkowie, mężczý́ni, kobiety, dzieci, niewolnicy i wolni, musieli na nowo przemyśleć i przekształcić w świetle wiary chrześcijańskiej ${ }^{51}$.

Rodzina, która przyjęła chrzest, stawała się miejscem, gdzie kształtowało się chrześcijańskie życie Kościoła. W domach rodzinnych gromadzono się, sprawowano Eucharystię, przekazywano w nich chrześcijańską naukę, przyjmowano wędrujących apostołów i misjonarzy. Dom stanowił punkt oparcia dla Ewangelii ${ }^{52}$, a do rodziny chrześcijańskiej przyłączali się inni, którzy uwierzyli. Na domowe spotkania można było zapraszać innych ludzi - była to okazja pozyskiwania ich dla wiary i dawania świadectwa ${ }^{53}$. To religijne znaczenie domu w pewnym sensie wywodzi się z pogaństwa. Dom był bowiem miejscem kultu rodzinnego zarówno u Rzymian, jak i u Greków. Podobnie było w domu żydowskim, w którym też dokonywał się przekaz wiary ${ }^{54}$.

Chrystus podniósł rangę małżeństwa i rodziny, a samemu małżeństwu nadał charakter sakralny. Chrześcijaństwo akcentuje wolną wolę dwojga osób świadomie wchodzących w przymierze małżeńskie, które od momentu ślubowania sobie miłości dozgonnej i nierozłącznej należą wyłącznie do siebie $^{55}$. Rodzina chrześcijańska ma swoje podstawy w chrześcijańskim małżeństwie opartym na sakramencie. Mowa tutaj o przymierzu, jakie dokonuje się między Bogiem a ludźmi, w którym sam Bóg umożliwia im wejście w przymierze z Nim. Dwoje, wchodząc w związek małżeński, odpowiada na to przymierze przez swoją wiarę i zawierzenie Bogu. Ufają oni, że On ich przeprowadzi przez wszelkie bariery życiowe i uzdolni do bycia jednością̧ ${ }^{56}$.

51 Por. J. Gnilka, Paweł z Tarsu. Apostoł i Świadek, tłum. W. Szymona OP, Kraków 2001, s. 224 .

52 „Przykładem może tu być dom żydowski, rodzina żydowska. Do tego wzorca mogły nawiązywać Kościoły chrześcijańskie. Już Jezus w swej mowie misyjnej polecił po wejściu do jakiegoś miasta lub wioski szukać godnego domu i tam - po wyrażeniu życzenia pokoju rozpoczynać głoszenie słowa (Łk 10,5-7)”. J. Gnilka, Pierwsi chrześcijanie - źródła i początki Kościoła, Kraków 2004, s. 420.

53 Por. J. Gnilka, Paweł $z$ Tarsu, dz. cyt., s. 236.

54 Por. J. Grześkowiak, U źródeł terminu „Kościół Domowy”, dz. cyt., s. 165.

55 Por. F. Adamski, Socjologia małżeństwa i rodziny, Warszawa 1984, s. 115-116; por. także: H. Langkammer, Małżeństwo w Nowym Testamencie, „Zeszyty Naukowe Katolickiego Uniwersytetu Lubelskiego" R. XXIII nr 3 (91), s. 33-44.

56 Por. Z. Kiernikowski, Dwoje jednym ciałem w Chrystusie. O chrześcijańskim małżeństwie i rodzinie jako sakramencie zbawienia, Warszawa 2001, s. 15. 
Jezus Chrystus przez swe dzieło odkupienia naprawił to, co zniszczył grzech, i dał ludziom nowe życie. Chrystus zwraca szczególną uwagę na nierozerwalność małżeństwa, wskazując na moment stworzenia: „Czy nie czytaliście, że Stwórca od początku stworzył ich jako mężczyznę i kobietę? (...) Dlatego opuści człowiek ojca i matkę i złączy się ze swoją żoną, i będą oboje jednym ciałem. A tak już nie są dwojgiem, lecz jednym ciałem. Co więc Bóg złączył, niech człowiek nie rozdziela" (Mt 19,4-6) ${ }^{57}$.

Mogą oni powołać się na osobę Jezusa Chrystusa i podobnie jak On wydać się dla drugiego - w tym przypadku dla swojego współmałżonka. Wbrew panującej powszechnie opinii chrześcijańskie małżeństwo nie jest umową dwóch osób, ale zawarciem przymierza z Bogiem, oczekiwaniem na wypełnienie się obietnic Boga i Jego dzieła w życiu małżonków. Bóg w przymierzu chce zwrócić uwagę człowieka na Jego wierność względem swoich obietnic $^{58}$. Wypełnia to, co powiedział przez proroka Jeremiasza: „(..) Umieszczę swe prawo w głębi ich jestestwa i wypiszę na ich sercach. Będę im Bogiem, oni zaś będą Mi narodem" (Jr 31,33).

W Starym Testamencie, w którym wielokrotnie jest mowa o przymierzu, porównywane jest ono do małżeństwa ${ }^{59}$. Wierność Boga w przymierzu ma nakłaniać do odkrywania i życia taką samą wiernością, która jest stała, bez względu na wierność drugiej strony. Tak jak Bóg, mimo wielokrotnej zdrady ze strony człowieka, pozostaje zawsze wierny, tak małżonkowie mają być wierni sobie ${ }^{60}$.

Przez zawarcie sakramentu małżeństwa dwoje ludzi wchodzi w przymierze z Bogiem, które On oferuje w Jezusie Chrystusie ${ }^{61}$. Jeśli tak się staje, małżonkowie nie są zdani wyłącznie na siebie samych, ale mają oparcie w Bogu, w jego wierności. Małżonkowie, wchodząc w to przymierze, doświadczają także relacji między sobą. Odkrywszy tajemnicę Jezusa, wszystko, co dzieje się w ich życiu, odnoszą do Stwórcy, do wierności, którą Bóg prezentuje $\mathrm{w}$ każdym przymierzu zawartym $\mathrm{z}$ ludźmi. Poznawszy dzieło

\footnotetext{
57 Por. L. Stachowiak, Biblijny obraz małżeństwa: od Starego do Nowego Testamentu, "Zeszyty Naukowe Katolickiego Uniwersytetu Lubelskiego" R. XXIII nr 3 (91), s. 17-24.

58 Por. Z. Kiernikowski, Dwoje jednym ciałem w Chrystusie, dz. cyt., s. 235; zob. szerzej: J. Załęski, Nierozerwalność małżeństwa według św. Pawła, Katowice 1992.

59 Por. A. Sarmiento, Małżeństwo chrześcijańskie. Podręcznik teologii małżeństwa i rodziny, Kraków 2002, s. 92-95.

60 Por. Z. Kiernikowski, Dwoje jednym ciałem w Chrystusie, dz. cyt., s. 235.

61 Por. A. Sarmiento, Małżeństwo chrześcijańskie, dz. cyt., s. 96-102.
} 
zbawienia i pojednania, zostali uzdolnieni do życia dwojga w jednym ciele, takiego życia, jakie było zamierzone przez Boga na początku. Chrześcijanin ma siłę egzystencji w tym, że poznał wierność Boga i nią żyje ${ }^{62}$. Dla chrześcijanina małżeństwo jest kontynuacją dzieła stworzenia, a dzieci - szczęściem rodziców ${ }^{63}$.

Jednym z celów chrześcijaństwa była zmiana nastawienia wewnętrznego ludzi i w związku z tym wpływ na ich relacje. Chodziło o istotną, niesłychanie głęboką przemianę człowieka, spowodowaną jego uczestnictwem w śmierci i zmartwychwstaniu Chrystusa. Wszelkie relacje, także te domowe, zostały przemienione nowym duchem. Ten, kto odkrył wartość życia w tajemnicy Jezusa Chrystusa, ma wewnętrzną potrzebę bycia poddanym drugiemu w Chrystusie. Przez to poddanie się coraz bardziej widzi i odkrywa siebie w Chrystusie, co jest bezpośrednim celem jego życia ${ }^{64}$. Tym, co wyznacza charakter wzajemnych więzi w małżeństwie, jest odniesienie do Chrystusa i Jego miłości. Autor listu do Efezjan daje dokładne wskazówki dotyczące życia małżeńskiego i rodzinnego. Jest to najważniejszy tekst Nowego Testamentu o „tajemnicy małżeństwa” (Ef 5,21-33) ${ }^{65}$.

Święty Paweł aż czterokrotnie wzywa mężów do miłowania żon, czyniąc z miłości podstawową zasadę małżeństwa, bo stanowi ona najważniejsze przykazanie Nowego Przymierza: „Przykazanie nowe daję wam, abyście się wzajemnie miłowali, tak jak Ja was umiłowałem; żebyście i wy tak się miłowali wzajemnie" (J 13,34) ${ }^{66}$.

W dalszej części spotykamy także wskazówki dla rodziców i ich dzieci, panów i niewolników: „Na wzór relacji Chrystus-Kościół mąż przedstawiony jest jako «głowa» $\mathrm{i}$ «zbawca» swojej żony. Jest to zupełnie nowy typ zwierzchności nad drugim, nieznany w strukturze rodzinnej greckiej czy rzymskiej. To prawda, że «żona ma poddać się mężowi we wszystkim», ale ma to być poddanie takie, jakie zachodzi między Chrystusem a nowym ludem Bożym"

\footnotetext{
62 Por. Z. Kiernikowski, Dwoje jednym ciałem w Chrystusie, dz. cyt., s. 247.

63 Por. A. G. Hamman, Życie codzienne pierwszych chrześcijan (95-197), dz. cyt., s. 289.

64 Por. Z. Kiernikowski, Dwoje jednym ciałem w Chrystusie, dz. cyt., s. 256-257.

65 Por. A. Sarmiento, Małżeństwo chrześcijańskie, dz. cyt., s. 98-102.

66 Por. J. Kłys, Rodzina dziedzictwem ludzkości - zarys etologii, cz. 1: Starożytność, Szczecin 1995, s. 59.

67 Por. A. Sikora, Rodzina w nowotestamentalnych „tablicach domowych”, w: Biblia o rodzinie, dz. cyt., s. 55.
} 
W Liście do Kolosan św. Paweł ukazuje prawidłowe relacje w domu i rodzinie chrześcijańskiej: „Żony, bądźcie poddane mężom, jak przystało w Panu. Mężowie, miłujcie żony i nie bądźcie dla nich przykrymi! Dzieci, bądźcie posłuszne rodzicom we wszystkim, bo to jest miłe w Panu. Ojcowie, nie rozdrażniajcie waszych dzieci, aby nie traciły ducha. Niewolnicy, bądźcie we wszystkim posłuszni doczesnym panom, nie służąc tylko dla oka, jak gdybyście się mieli ludziom przypodobać, lecz w szczerości serca, bojąc się [prawdziwego] Pana. Cokolwiek czynicie, z serca wykonujcie jak dla Pana, a nie dla ludzi" (Kol 3,18-23).

Odniesienie to ma swe korzenie w tzw. „tablicach domowych" ${ }^{\text {. Nazwą }}$ tą określa się zestawy pouczeń i wskazań moralnych skierowanych do poszczególnych osób, tworzących rodzinę nie tylko chrześcijańską, ale także pogańską - zarówno grecką, jak i rzymską. W Nowym Testamencie o pełnych tablicach domowych mówi się w: Kol 3,18-4,1; Ef 5,22-6,9; 1 Tm 2,815 i 6,1n; Tt 2,1-10 i 1 P 2,13-3,7. W rodzinie chrześcijańskiej nie są one jednak tymi samymi tablicami, co w rodzinie pogańskiej, bo zostały prześwietlone mocą Ewangelii Jezusa Chrystusa ${ }^{69}$.

Sformułowane zasady były niezwykle postępowe, bowiem głoszono je i urzeczywistniano w środowiskach, w których władza ojca rodziny nie podlegała ograniczeniom. W czasie gdy św. Paweł pisał ten tekst, kobieta w swoim środowisku, a szczególnie w hierarchii społecznej, znajdowała się zdecydowanie niżej niż mężczyzna. Paweł zatem dowartościowuje kobietę i podnosi jej godność. Odnosi się również do dzieci, którym przypomina o zasadzie posłuszeństwa rodzicom, wynikającej z przykazania Bożego, a jednocześnie przestrzega ojców przed nadużywaniem rodzicielskiej władzy: „A [wy], ojcowie, nie pobudzajcie do gniewu waszych dzieci, lecz wychowujcie je w karności, napominając, jak [chce] Pan” (Ef 6,4). Autorytet $\mathrm{w}$ rodzinie, podobnie jak władza w społeczności cywilnej, znalazł swoje odniesienie i źródło w Bogu: „Dzieci, bądźcie posłuszne w Panu waszym rodzicom, bo to jest sprawiedliwe” (Ef 6,1). „Na podstawie tekstów «tablic» rodzina chrześcijańska jawi się jako społeczność inspirowana przede

68 Stanowią one zestawienie obowiązków moralnych. Por. A. Sikora, Rodzina w nowotestamentalnych „tablicach domowych”, dz. cyt., s. 47.

69 Por. Z. Kiernikowski, Dwoje jednym ciałem w Chrystusie, dz. cyt., s. 251. 
wszystkim wartościami ewangelicznymi. Sam Chrystus staje się dla każdego stanu w rodzinie wzorem życia i postępowania"70.

W kulturze grecko-rzymskiej dom był czymś więcej niż mieszkaniem, był życiową przestrzenią. Tu żyli i pracowali nadający znaczenie całemu domowi - małżonek i ojciec domu - pater familias, jego żona i dzieci, niewolnicy i niewolnice, krewni i znajomi. Oczywiście istniały domy większe i mniejsze, w każdym z nich jednak to mężczyzna - jako małżonek, ojciec dzieci i pan niewolników - był głową rodziny.

Chrześcijanie zachowywali żydowski zwyczaj modlenia się w ciągu dnia $^{71}$. W tym także chrześcijańska wspólnota chciała naśladować przykład samego Chrystusa (por. Mt 14,19; Dz 27,35). „Nadawała ona rytm dniom i czasowi, zmieniała życie chrześcijanina $\mathrm{w}$ «jedno długie święto» wewnątrz świata"72.

Dla Pawła jakość spełnianych codziennych powinności domowych była wykładnikiem autentycznej religijności (por. 1 Tm 5,8). Dom chrześcijański stawał się miejscem, w którym rozwijało się życie według Ewangelii. Wspólnotę małżeńską uznawano za aktywne i skuteczne narzędzie ewangelizacji, za podmiot i miejsce duszpasterstwa ${ }^{73}$. Najważniejszym aspektem domu były braterska atmosfera i wspólnota miłości. Obcowanie ze sobą różnych grup i stanów społecznych, starszych i młodych, niewolników i wolnych, ubogich i bogatych, kobiet i mężczyzn, ułatwiało niwelowanie i przezwyciężanie dzielących różnic: „Nie ma już Żyda ani poganina, nie ma już niewolnika ani człowieka wolnego, nie ma już mężczyzny ani kobiety, wszyscy bowiem jesteście kimś jednym w Chrystusie Jezusie” (Ga 3,28), oraz: „A tu już nie ma Greka ani Żyda, obrzezania ani nieobrzezania, barbarzyńcy, Scyty, niewolnika, wolnego, lecz wszystkim we wszystkich [jest] Chrystus" (Kol 3,11). Jedność rodziny umożliwiała przeżywanie wiary w konkretnych warunkach życia. Przemieniała dawne struktury małżeńsko-rodzinne nowym duchem.

\footnotetext{
70 A. Sikora, Rodzina w nowotestamentalnych „tablicach domowych”, dz. cyt., s. 65-66.

71 Podobnie jak w domach grecko-rzymskich znajdowały się ołtarzyki lub kapliczki poświęcone bóstwom, tak też w domach chrześcijańskich można było spotkać osobne miejsce na modlitwę. Por. A. G. Hamman, Życie codzienne pierwszych chrześcijan (95-197), dz. cyt., s. 244-256.

72 Por. A. G. Hamman, Życie codzienne pierwszych chrześcijan (95-197), dz. cyt., s. 249.

73 J. Kłys, Rodzina dziedzictwem ludzkości - zarys etologii, dz. cyt., s. 55.
} 
Dom stał się miejscem krzewienia wiary, dawania świadectwa o Chrystusie, pozyskiwania nowych członków Kościoła, budowania nowej wspólnoty przemienionej przez Ewangelię. W ten sposób chrześcijanie stawali się wiarygodnymi świadkami działania Jezusa Chrystusa w ich życiu.

Życie rodzinne w czasach rzymskich nacechowane było dużą religijnością i otwartością na Boga. Przejawiało się to w samej strukturze rodziny, w relacjach między mieszkańcami domu, a także gdy w domu przebywali goście i przybysze. To w nim dokonywał się cały przekaz wiary i tradycji narodu. Szczególnie znaczenie miała osoba ojca, który był niejako domowym kapłanem, przedstawicielem i głową rodziny. On decydował o sprawach wiary w rodzinie i niejako ukazywał samego Boga Ojca. Chrystus jednak wywyższył godność małżeństwa i rodziny, dlatego rodzina chrześcijańska, mająca swoje fundamenty w kulturze grecko-rzymskiej i żydowskiej, przez swoje relacje i zaangażowanie ukazuje na polu ewangelizacji piękno Dobrej Nowiny o Chrystusie oraz to, że Bóg nadal działa i jest obecny w ich życiu.

\section{Podsumowanie}

Ewangelizacja polega na doprowadzeniu człowieka do ścisłych relacji z Chrystusem, które potwierdzone są świadectwem życia chrześcijańskiego. Jej podstawą jest wewnętrzna przemiana i przylgnięcie do Chrystusa. Ewangelizacja to dotarcie do człowieka z Dobrą Nowiną, obecną w całym klimacie Kościoła, w całym życiu chrześcijan ${ }^{74}$. Fundamentalne znaczenie w tym dziele ma rodzina, w której dokonuje się pierwsze otwarcie na Boga i drugiego człowieka. To właśnie w rodzinie w pierwszych wiekach chrześcijaństwa Ewangelia znalazła miejsce, w którym przemieniała relacje małżeńsko-rodzinne, a co za tym idzie - także społeczne.

Nowy Testament nie mówi wprost o rodzinie jako „domowym Kościele”. Ukazuje jednak ważną rolę rodziny i jej domu w rozwoju Kościoła, w jego życiu sakramentalnym i posłannictwie ewangelizacyjnym. To właśnie dom rodzinny sprzyjał Ewangelii i tworzeniu się pierwszych wspólnot chrześcijańskich. Wielką rolę odgrywał ojciec, który był panem i opiekunem. Gdy pan domu przyjmował chrzest, cały dom, wraz z wszystkimi jego mieszkańcami,

74 Por. M. Czajkowski, Nowa Ewangelizacja, „Znak” R. XLIV (10) nr 449, s. 62. 
stawał się chrześcijański. Dopóki chrześcijanie nie mieli własnych świątyń, dom rodzinny odgrywał znaczącą rolę w dziele rozszerzania się słowa Bożego przez świadectwo wiary członków rodziny, przyjmowanie do domu misjonarzy, użyczanie gościny chrześcijanom, świadczenie pomocy wszystkim będącym w potrzebie, a także służył do sprawowania liturgii. Fundamentów takich działań dopatrujemy się w rodzinie żydowskiej i grecko-rzymskiej, która miała istotny wpływ na rozwój chrześcijaństwa. Zanim jednak do tego doszło, rodzina musiała odczuć wielką moc, jaką niesie Ewangelia.

To samo dokonało się zapewne w rodzinach w Kościele pierwotnym, np. w domu Pryscylli i Akwili, którzy poświęcili się dziełu ewangelizacji. Przez swoje świadectwo wiary i zaangażowanie uczynili oni ze swego domu Kościół, byli nawet gotowi głosić Ewangelię razem z Pawłem w innych miastach. Stali się oni wzorem rodziny misyjnej, zatroskanej o rozwój Dobrej Nowiny, czego dowodem jest ich udanie się razem z Pawłem z Koryntu do Efezu oraz wyjaśnienie chrześcijańskiej nauki Apollosowi. To w ich domu gromadził się członkowie pierwotnego Kościoła. Prowadzili oni także innych do poznania Chrystusa.

Ewangelizacyjna posługa rodziny musi mieć charakter misyjny, bo właśnie przez to rodzina ukazuje powszechną misyjność Kościoła. Małżonkowie mają dawać świadectwo o Chrystusie „aż po krańce ziemi” (Dz 1,8), mają być „prawdziwymi i właściwymi misjonarzami miłości i życia”75. W tym duchu powinny ożywiać całą wspólnotę małżeńsko-rodzinną, ponieważ jak stwierdza adhortacja apostolska Familiaris consortio: „Kościół domowy jest posłany do tego, by był jaśniejącym znakiem obecności Chrystusa i Jego miłości także dla ludzi stojących «daleko», dla rodzin, które jeszcze nie wierzą i dla tych rodzin chrześcijańskich, które już nie żyją konsekwentnie wedle otrzymanej wiary: jest wezwany, ażeby przykładem i świadectwem swoim oświecał tych, co szukają prawdy"76.

Konkretne formy realizacji tego dynamizmu rodziny to: udawanie się małżeństw lub rodzin na tereny misyjne, pielęgnowanie powołań misyjnych u dzieci, całe dzieło wychowania w rodzinie ${ }^{77}$. Możemy to szczególnie zauważyć w rodzinach, które wstąpiły na Drogę Neokatechumenalną ${ }^{78}$ oraz

\footnotetext{
75 Jan Paweł II, Adhortacja apostolska Familiaris Consortio, 54.

76 Jan Paweł II, Adhortacja apostolska Familiaris Consortio, 54.

77 Jan Paweł II, Adhortacja apostolska Familiaris Consortio, 54.

78 Por. Art. 33, w: Droga Neokatechumenalna - Statut, Warszawa 2002, s. 50.
} 
w „Domowym Kościele” Ruchu Światło-Życie. Jest to forma obecności Kościoła przypominająca sposób postępowania św. Pawła, któremu pomagały rodziny, m.in. małżeństwo Pryscylli i Akwili.

Wspólnota rodzinna stanowi szczególne miejsce ewangelizacji. Paweł VI w Evangelii nuntiandi stwierdził, że „rodzinę, podobnie jak Kościół, należy uważać za pole, na które przynosi się Ewangelię i z którego ona się rozkrzewia. Dlatego w łonie rodziny, świadomej tego zadania, wszyscy jej członkowie ewangelizują, a także podlegają ewangelizacji" ${ }^{39}$. Jest to ewangelizacja wewnątrz rodziny, ale także wobec innych rodzin poprzez „świadectwo zżycia prawdziwie i ściśle chrześcijańskiego"80.

Rodzina chrześcijańska stanowi konkretne środowisko i życiową przestrzeń, w której Dobra Nowina dosięga ludzi, aby przekształcić ich od wewnątrz i odrodzić. Rodzina, wypełniając swoją posługę, staje się Kościołem i „buduje Kościół”" Synod w Pueblo przypomniał, iż przyszłość ewangelizacji zależy w dużej mierze od Domowego Kościoła ${ }^{82}$ : „to posłannictwo apostolskie rodziny jest zakorzenione $\mathrm{w}$ chrzcie świętym, a przez laskę sakramentu małżeństwa otrzymuje nową moc dla przekazywania wiary, dla uświęcenia i przemiany współczesnego społeczeństwa wedle zamysłu Bożego" ${ }^{\prime 3}$.

\section{Bibliografia}

Adamski F., Socjologia małżeństwa i rodziny, Warszawa 1984.

Biblia o rodzinie, red. G. Witaszek, Lublin 1995.

\footnotetext{
79 Paweł VI, Adhortacja apostolska Evangelii nuntiandi, 71.

80 Paweł VI, Adhortacja apostolska Evangelii nuntiandi, 41.

81 Jan Paweł II, Adhortacja apostolska Familiaris Consortio, 15.

82 Por. Jan Paweł II, Przemówienie na III Konferencji Ogólnej Episkopatów Ameryki Łacińskiej (28 stycznia 1979 r.), „Acta Apostolica Sedis” 71 (1979), s. 204; zob. szerzej: C. A. Anderson, La famiglia, soggetto Della nova evagelizzazione: vocazione e missione della famiglia oggi, w: Famiglia e nuova evangelizzazione: la chiave dell'annuncio, ed. L. Melina. J. Granados, Siena 2012, s. 93-105.

83 Jan Paweł II, Adhortacja apostolska Familiaris Consortio, 52.
} 
Cyran W., Rola Ducha Świętego $w$ dziele ewangelizacji (na podstawie Dz 10,44-48), „Częstochowskie Studia Teologiczne” XXI-XXII (19931994), s. 15-36.

Czajkowski M., Nowa Ewangelizacja, „Znak” R. XLIV (10) nr 449, s. 56-62.

Dhavamon M., Ewangelizacja, dialog i rozwój - wybrane dokumenty Międzynarodowej Konferencji Teologicznej w Nagpur w 1971 r., red. M. Dhavamon, tłum. J. Marzęcki, Warszawa 1986.

Droga Neokatechumenalna - Statut, Warszawa 2002.

Famiglia e nuova evangelizzazione: la chiave dell'annuncio, ed. L. Melina, J. Granados, Siena 2012.

Fisichella R., La nuova evangelizzazione, Milano 2011.

Fitzmyer J. A., Lettera ai Romani. Commentario critico-teologico, Casale Monferrato 1999.

Gnilka J., Paweł z Tarsu. Apostoł i Świadek, tłum. W. Szymona OP, Kraków 2001

Gnilka J., Teologia Nowego Testamentu, tłum. W. Szymona OP, Kraków 2002.

Grześkowiak J., Misterium małżeństwa. Sakrament małżeństwa jako symbol przymierza Boga z ludźmi, Poznań 1993, s. 231-245.

Grześkowiak J., U źródeł terminu „Kościół Domowy”, „Roczniki Teologiczne" t. XXXII (1985) 2, s. 161-172.

Hamman A. G., Życie codzienne pierwszych chrześcijan (95-197), tłum. U. Sudolska, A. Guryn, Warszawa 1990.

Hergesel T., Ewangelizacja w Biblii, w: W kręgu Dobrej Nowiny, red. J. Szlaga, Lublin 1984.

Hergesel T., Biblijna idea ewangelizacji, „Colloquium Salutis, Wrocławskie Studia Teologiczne" 11 (1979), s. 255-266.

Jan Paweł II, Przemówienie na III Konferencji Ogólnej Episkopatów Ameryki Łacińskiej (28 stycznia 1979 r.), „Acta Apostolica Sedis” 71 (1979), s. 204-205.

Kempiak R., „Będziecie moimi świadkami [...] aż po krańce ziemi” (Dz 1,8). Kompozycja Dziejów Apostolskich, „Scriptura Sacra” 1 (1997) 1, s. 75-88.

Kiernikowski Z., Dwoje jednym ciałem w Chrystusie. O chrześcijańskim matżeństwie i rodzinie jako sakramencie zbawienia, Warszawa 2001.

Klauck H. J., Kościół Domowy w okresie przedkonstantyńskim, „Vox Patrum. Antyk Chrześcijański” 8-9, s. 177-191.

Klauck H. J., Wczesnochrześcijańska wspólnota kościelna, Kraków 1995. 
Kłys J., Rodzina dziedzictwem ludzkości - zarys etologii, cz. 1: Starożytność, Szczecin 1995.

Kongregacja Nauki Wiary, Nota doktrynalna na temat pewnych aspektów ewangelizacji, „L'Osservatore Romano” wyd. pol. 2 (2008) nr 2, s. 32-33.

Langkammer H., Małżeństwo w Nowym Testamencie, „Zeszyty Naukowe Katolickiego Uniwersytetu Lubelskiego" R. XXIII nr 3 (91), s. 33-43.

Lewek A., Nowa ewangelizacja w duchu Soboru Watykańskiego II, Katowice 1995.

Łach J., Rola gminy jerozolimskiej w pierwotnym Kościele (Dz 2,42-47; 4,3235; 5,12-16), w: Scrutamini Scripturas - Ksiega pamiątkowa z okazji jubileuszu ks. prof. Stanisława Łacha, Kraków 1980, s. 88-89.

Marczewski M., Miejsce i rola małżeństw w misji wczesnochrześsijańskiej na przykładzie Nowego Testamentu (Kościół Domowy), „Vox Patrum. Antyk Chrześcijański" 15 (1988), s. 575-583.

Murphy-O'Connor J., Prisca and Aquila, „Biblia Revuo” 8/6 (1992), s. 40-62.

Papieska Komisja Biblijna, Naród Żydowski i jego Święte Pisma w Biblii chrześcijańskiej, Kielce 2002.

Przyczyna W., Teologia ewangelizacji, Kraków 1992.

Pytel. J. K., Gościnność w Biblii - studium źródtowo-porównawcze, Poznań 1990.

Rakocy R., Przyczynek do dyskusji na temat kompozycji dziejów Apostolskich, „Roczniki Teologiczne” t. XLII (1995) 1, s. 103-110.

Romaniuk K., Święty Paweł o kobietach, „Colloqium Salutis. Wrocławskie Studia Teologiczne” 21-22 (1989-1990), s. 51-98.

Sarmiento A., Małżeństwo chrześcijańskie. Podręcznik teologii małżeństwa i rodziny, Kraków 2002.

Simon M., Cywilizacja wczesnego chrześcijaństwa, tłum. E. Bąkowska, Warszawa 1981.

Stachowiak L., Biblijny obraz małżeństwa: od Starego do Nowego Testamen$t u$, „Zeszyty Naukowe Katolickiego Uniwersytetu Lubelskiego” R. XXIII nr 3 (91), s. 17-24. 
